\title{
Optimization of Microwave-assisted Extraction of Phenolics from Organic Strawberry Using Response Surface Methodology
}

\author{
Aysel ELiK ${ }^{1 *}$, Derya KOÇAK YANIK ${ }^{1}$, Fahrettin GÖĞÜŞ ${ }^{1}$ \\ ${ }^{1}$ University of Gaziantep, Engineering Faculty, Gaziantep, Turkey \\ *Corresponding author: aelik@gantep.edu.tr
}

\begin{abstract}
The effects of microwave- assisted extraction (MAE) were investigated on extraction of phenolic compounds from strawberry fruit. Response surface methodology (RSM) was used to optimize the extraction conditions. A face-centered central composite design (FCCCD) was employed to determine the effects of independent variables such as microwave power (100-300 W), extraction time (2-16 min) and solvent to sample ratio $\left(5: 1-25: 1 \mathrm{~mL} \mathrm{~g}^{-1}\right)$ on the extraction yield and total phenolic content (TPC). Optimized conditions were determined as $265 \mathrm{~W}$ of microwave power, 2 min of extraction time and 24:1 $\mathrm{mL} \mathrm{g}^{-1}$ of solvent to sample ratio. The maximum predicted extraction yield and TPC under the optimum conditions were $8.23 \%$ and $19.65 \mathrm{mg} \mathrm{GAE} \mathrm{g}^{-1}$ dry strawberry, respectively. Total anthocyanin content (TAC), DPPH.EC 50 and FRAP values of extracts produced at optimum conditions were determined as $2.3 \mathrm{mg} \mathrm{Cyn}$-3-glu g $^{-1}$ dry strawberry, $1.67 \mathrm{mg}$ dry strawberry $\mathrm{mL}^{-1}$ and $197.83 \mu$ moles TE $\mathrm{g}^{-}$ ${ }^{1}$ dry strawberry, respectively.
\end{abstract}

Key Words: Microwave-assisted extraction, Strawberry, Phenolics, Response surface methodology

\section{Yanıt Yüzey Metodolojisi Kullanılarak Organik Çilekten Mikrodalga Destekli Fenolik Ekstraksiyonunun Optimizasyonu}

Öz

Çilek meyvesinden fenolik maddelerin ekstraksiyonu üzerine mikrodalga destekli ekstraksiyonun etkisi çalışılmıştır. Ekstraksiyon koşullarını optimize edebilmek için yanıt yüzey metodolojisi kullanılmıştır. Yüzmerkezli merkezi kompozit tasarım (FCCCD), mikrodalga gücü (100-300 W), ekstraksiyon süresi (2-16 dk) ve çözgen numune oranı $\left(5: 1-25: 1 \mathrm{~mL} \mathrm{~g}^{-1}\right)$ gibi bağımsız değişkenlerin ekstraksiyon verimi ve toplam fenolik içeriği (TPC) üzerine etkilerini belirlemek için kullanılmıştır. Optimize edilmiş koşullar; $265 \mathrm{~W}$ mikrodalga gücü, $2 \mathrm{dk}$ ekstraksiyon süresi ve $24: 1 \mathrm{~mL} \mathrm{~g}^{-1}$ çözgen numune oranı olarak belirlenmiştir. Optimum koşullar altında, tahmin edilen maksimum ekstraksiyon verimi ve TPC sırasıyla \% 8.23 ve 19.65 mg GAE $\mathrm{g}^{-1}$ kuru çilek'tir. Optimum şartlarda üretilen ekstraktların, toplam antosiyanin içeriği (TAC),

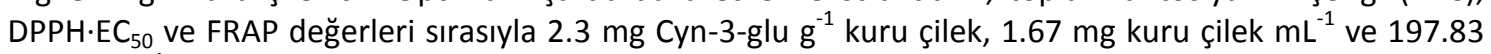
$\mu \mathrm{mol} \mathrm{TE} \mathrm{g}^{-1}$ kuru çilek olarak belirlenmiştir.

Anahtar Kelimeler: Mikrodalga destekli ekstraksiyon, Çilek, Fenolikler, Yanıt yüzey metodolojisi

\section{Introduction}

Strawberry belongs to the Rosaceae family, the genus Fragaria (Sargent et al., 2007) and is one of fruit with high demand both in Turkey and worldwide. Strawberry grows wildly in especially Mediterranean region of Turkey (Kafkas et al., 2007). According to data of Food and Agriculture Organization (FAO), Turkey with 376070 tonnes is one of the biggest strawberry 
producers around the world (FAOSTAT, 2014).

Strawberry fruit contains high amount of phytochemicals, most of which are phenolic compounds. Phenolics have one or more aromatic rings with hydroxyl groups (Paredes-Lopez et al., 2010). They are secondary plant metabolites and are made up of several classes of compounds including flavonoids such as anthocyanins, catechins and flavonols, phenolic acids, tannins and stilbenes. These phenolics present beneficial effects in human health and prevent chronic diseases (Ljevar et al., 2016). Strawberries have a great antioxidant capacity due to including phenolics such as anthocyanins (Ayala-Zavala et al., 2007; Hornedo-Ortega et al., 2016). In addition, phenolics have also been found effective in other biological mechanisms such as anti-inflammation action (Zhang and Tsao, 2016), cancer enzyme inhibition (Huang et al., 2009), antimutagenic activity (Nile and Park, 2014), antimicrobial activity (Nohynek et al., 2006), neuroprotective property (Fortalezas et al., 2010), nitric oxide production inhibition (Del Rio et al., 2010) and chemoprotective enzyme inducement (Yang and Liu, 2009).

The increasing interest in bioactive components is accompanied by a requirement to investigate new extraction techniques that can be more effective. Traditional techniques such as soxhlet, maceration and solvent extraction are used for extraction of valuable compounds from plant materials for many years (Carniel et al., 2016). However, classical extraction methods are time consuming, require large volumes of solvent. Moreover, they often generate heat, consequently lead to degradation of thermolabile compounds. Therefore, faster and efficient extraction techniques are being explored such as accelerated solvent extraction (ASE), ultrasound-assisted extraction (UAE), supercritical-fluid extraction (SFE), extraction with supercritical or subcritical water and microwave-assisted extraction (MAE) (Bai et al., 2007; GarciaSalas et al., 2010; Azmir et al., 2013).

MAE is an extraction technique that use microwave irradiation to generate heat, causing a cell disruption which makes extraction of a target compound from materials easier (Chan et al., 2011). MAE has many advantages over more traditional extraction methods, including considerably reduced extraction time and solvent usage, better extraction yield and suitable for heatsensitive constituents. Additionally, the uniform nature of microwave radiation aids in the repeatability and reproducibility of extractions (Kaufmann and Christen, 2002; Mandal et al., 2007). MAE is gaining interest due to advantages mentioned above but any study regarding MAE of phenolic compounds from strawberry has not been reported yet.

Main objectives of the present study were to evaluate the influences of extraction variables (microwave power, extraction time and solvent to sample ratio) on the extraction yield and total phenolic content (TPC) and to apply the response surface methodology (RSM) approach to optimize the extraction variables for phenolic extraction from strawberry.

\section{Material and Methods}

\section{Fruits and reagents}

Organic strawberries (Fragaria ananassa Duch., family Rosaceae) were purchased from an organic farm, Bursa, Turkey. Strawberries were stored in freezer at $-20{ }^{\circ} \mathrm{C}$ until processing.

Ethanol, citric acid, folin-ciocalteu's phenol reagent, sodium carbonate $\left(\mathrm{Na}_{2} \mathrm{CO}_{3}\right)$, gallic acid, sodium acetate trihydrate 
$\left(\mathrm{C}_{2} \mathrm{H}_{3} \mathrm{NaO}_{2} \cdot 3 \mathrm{H}_{2} \mathrm{O}\right)$,

1,1-diphenyl-2picrylhydrazyl (DPPH), potassium chloride $(\mathrm{KCl})$, Iron(III) chloride hexahydrate $\left(\mathrm{FeCl}_{3} \bullet 6 \mathrm{H}_{2} \mathrm{O}\right)$, concentrated $\mathrm{HCl}$ and trolox were purchased from Sigma- Aldrich. 2,4,6tripyridyls-triazine (TPTZ) was purchased from Fluka. All other reagents and solvents used were of analytical or chromatograptic grade.

\section{MAE procedure}

MAE was carried out on an open-vessel microwave system (CEM Corporation, USA, 3100 Smith Farm Road, Matthews, NC 28105-5044). Ethanol was used as extraction solvent since ethanol has low toxicity and high efficiency for phenolic extraction (Wu et al., 2012). Total volume was kept constant at $72 \mathrm{~mL}$. Strawberries were crushed by using Waring blender (HGB150, USA). Crushed strawberries were mixed with ethanol and extracted using different power, extraction time and solvent to sample ratio according to experimental design conditions. After extraction process, the mixture was centrifuged at $6000 \mathrm{rpm}$ at $25{ }^{\circ} \mathrm{C}$ for $10 \mathrm{~min}$ and supernatants were recovered. Solvent was evaporated using the rotary vacuum evaporator (Model VV 2000, Heidolph, Germany) and extracts were stored at $-18{ }^{\circ} \mathrm{C}$ until the analyses were performed. The extraction yield was calculated by using following Equation (1).

Extraction yield $(\%)=(g$ extract $/ g$ strawberry) x 100

\section{Determination of moisture content}

3-5 g of strawberry were weighed on aluminum tray and put in a drying oven at $105{ }^{\circ} \mathrm{C}$ until achieving constant weight. The dried strawberries were weighed again and the dried matter that remained was determined. All measurements were done in triplicate and the average values were determined.

Total phenolic content (TPC) by FolinCiocalteu's assay

The Folin-Ciocalteu method adapted from Singleton et al. (1999) was used to determine total phenolic compound of samples. TPC values were expressed as gallic acid equivalents (GAE) in mg per $g$ of dry strawberry. All measurements were done in triplicate and the average values were determined.

Total anthocyanin content (TAC) by $\mathrm{pH}$ differential method

Anthocyanins content of samples was determined by the pH-differential method (Lee et al., 2005). Total anthocyanins of samples were expressed as the amount of cyanidin-3-glucoside equivalents with unit of mg per g dry strawberry. All measurements were done in triplicate and the average values were determined.

\section{DPPH-scavenging activity assay}

The DPPH radical scavenging activity of samples was measured according to procedure described by Brand-Williams et al. (1995). The results were expressed as a $\mathrm{DPPH}$ free radical scavenging activity $\mathrm{EC}_{50}$ value, which reflects $50 \%$ depletion of the free radical. DPPH tests were done in triplicate and the average values were determined.

Ferric reducing antioxidant power (FRAP) assay

The total antioxidant potential of strawberry fruit and extract was determined using a modification FRAP assay of Benzie and Strain (1996). Results were expressed as trolox equivalents (TE) in $\mu$ moles per $g$ of dry 
strawberry. All measurements were done in triplicate and the average values were determined.

Experimental Design and Optimization by Response Surface Methodology

RSM was chosen to determine the optimal conditions for MAE from organic strawberry. The RSM was performed using Design Expert (Stat-Ease, Design-Expert software, version 7). The effect of the independent variables; microwave power (100-300 W), extraction time (2-16 min) and solvent to sample ratio $\left(5: 1-25: 1 \mathrm{~mL} \mathrm{~g}^{-1}\right)$ was investigated using a three-factor, three-level face-centered central composite design central composite design (FCCCD). The complete design consists of 20 runs, including six replications of the centre points.

The fitness of the model was determined by evaluating the Fisher test value ( $F$-Value) and the coefficient of determination $\left(R^{2}\right)$ as obtained from an analysis of variance (ANOVA). The level of significance for all tests was set at $95 \%$ confidence level. The generalized quadratic model for the responses is given in Equation (2):

$$
\begin{gathered}
Y_{1,2}=\beta_{0}+\sum_{\mathrm{i}=1}^{\mathrm{i}=\mathrm{n}} \beta_{i} X_{i}+\sum_{\mathrm{i}=1}^{\mathrm{i}=\mathrm{n}} \beta_{i i} X_{i}^{2}+ \\
\sum_{\mathrm{i}=1}^{\mathrm{i}=\mathrm{n}} \sum_{\mathrm{j}=1}^{\mathrm{j}=\mathrm{n}} \beta_{i j} X_{i} X_{j}
\end{gathered}
$$

Where $Y_{1}$ is the response of extraction yield and $Y_{2}$ is the response of TPC. $b_{0}, b_{i}, b_{i i}$ and $B_{i j}$ are the regression coefficients for the model constant, linear, quadratic and interaction terms of independent variables $i$ and $j$, respectively, and $X_{i}$ and $X_{j}$ are the independent variables.

\section{Results and Discussion}

\section{Experimental design and model fitting}

The first step in this study was to determine the selection of the proper ranges of process parameters. The ranges of independent variables were selected for optimization based on previous studies (Mandal et al., 2007; Zheng et al., 2013) that deal with the extraction of phenolics by MAE and preliminary experiments. Processing parameters were decided as $100-300 \mathrm{~W}$ of microwave power, 2-16 $\mathrm{min}$ of extraction time and 5:1-25:1 $\mathrm{mL} \mathrm{g}^{-1}$ of solvent to sample ratio. The responses were the extraction yield and TPC. Table 1 shows the effect of microwave power, extraction time and solvent to sample ratio on yield and TPC of extracts obtained from strawberry. According to results obtained from experimental design set, the extraction yield and TPC ranged from 6.90 to $9.69 \%$ and 16.59 to $21.58 \mathrm{mg} \mathrm{GAE} \mathrm{g}^{-1}$ dry strawberry, respectively.

Experimental data were statistically analyzed through ANOVA and results were shown in Table 2. From Table 2, the lack of fit values of the selected models were clearly not significant $(p>0.05)$. This indicated that this model could explain suitably the relationship between the response and the independent variables. This was also confirmed by the high values of $R^{2}(0.9083$ for the extraction yield and 0.9441 for TPC). 
Table 1. Three-factor. three-level face-centered central composite design (FCCCD) and results for three variables studied

Çizelge 1. Çalışılan üç değişken için üç faktörlü üç seviyeli yüz-merkezli merkezi kompozit tasarım (FCCCD)

\begin{tabular}{|c|c|c|c|c|c|}
\hline $\begin{array}{l}\text { Standard } \\
\text { Order }\end{array}$ & $\begin{array}{l}\text { Microwave } \\
\text { power } \\
\text { (W) }\end{array}$ & $\begin{array}{l}\text { Extraction time } \\
\qquad(\min )\end{array}$ & $\begin{array}{l}\text { Solvent to } \\
\text { sample ratio } \\
\left(\mathrm{mL} \mathrm{g}^{-1}\right)\end{array}$ & $\begin{array}{l}\text { Extraction } \\
\text { yield (\%) }\end{array}$ & $\begin{array}{l}\text { TPC (mg GAE g } \\
\text { dry strawberry) }\end{array}$ \\
\hline $\begin{array}{l}\text { Standart } \\
\text { Dizi }\end{array}$ & $\begin{array}{c}\text { Mikrodalga } \\
\text { gücü (W) }\end{array}$ & $\begin{array}{c}\text { Ekstraksiyon } \\
\text { süresi (dk) }\end{array}$ & $\begin{array}{l}\text { Çözgen } \\
\text { numune oranı } \\
\left(m L g^{-1}\right)\end{array}$ & $\begin{array}{c}\text { Ekstraksiyon } \\
\text { verimi (\%) }\end{array}$ & $\begin{array}{c}T P C \text { (mg GAE } g^{-1} \\
\text { kuru çilek) }\end{array}$ \\
\hline 1 & 100 & 2 & $5: 1$ & 6.90 & 18.21 \\
\hline 2 & 300 & 2 & $5: 1$ & 7.45 & 18.04 \\
\hline 3 & 100 & 16 & $5: 1$ & 7.68 & 17.80 \\
\hline 4 & 300 & 16 & $5: 1$ & 8.69 & 16.72 \\
\hline 5 & 100 & 2 & $25: 1$ & 7.87 & 18.72 \\
\hline 6 & 300 & 2 & $25: 1$ & 7.96 & 19.86 \\
\hline 7 & 100 & 16 & $25: 1$ & 7.82 & 21.58 \\
\hline 8 & 300 & 16 & $25: 1$ & 8.44 & 20.49 \\
\hline 9 & 100 & 9 & $15: 1$ & 9.69 & 17.47 \\
\hline 10 & 300 & 9 & $15: 1$ & 9.53 & 16.59 \\
\hline 11 & 200 & 2 & $15: 1$ & 8.50 & 17.54 \\
\hline 12 & 200 & 16 & $15: 1$ & 8.97 & 19.41 \\
\hline 13 & 200 & 9 & $5: 1$ & 7.84 & 17.19 \\
\hline 14 & 200 & 9 & $25: 1$ & 8.76 & 20.15 \\
\hline 15 & 200 & 9 & $15: 1$ & 9.00 & 17.20 \\
\hline 16 & 200 & 9 & $15: 1$ & 9.47 & 17.27 \\
\hline 17 & 200 & 9 & $15: 1$ & 8.93 & 17.09 \\
\hline 18 & 200 & 9 & $15: 1$ & 9.37 & 17.23 \\
\hline 19 & 200 & 9 & $15: 1$ & 9.11 & 17.18 \\
\hline 20 & 200 & 9 & $15: 1$ & 9.22 & 17.89 \\
\hline
\end{tabular}

Regression models for extraction yield and TPC were obtained from the regression results and backward elimination by means of elimination the non-significant factors in the models. Some linear, quadratic or interaction terms were not eliminated by backward elimination to keep the hierarchy of the model even if they were not significant. The resulting equations for the fitted model are shown below:
The extraction yield $=9.28+0.21 * \mathrm{Mw}+$ $0.29 * T i+0.23 * R a-0.20 * T i * R a-0.50 * T i^{2}$ $-0.94 * R a^{2}$

$$
\begin{aligned}
& T P C=17.40-0.21 * M w+0.36 * T i+ \\
& 1.28 * R a-0.39 * M w^{*} T i+0.65 * T i^{*} R a- \\
& 0.51 * M w^{2}+0.94 * T i^{2}+1.13 * R a^{2}
\end{aligned}
$$

where $M w$ is microwave power, $T i$ is extraction time and $R a$ is solvent to sample ratio. 
Table 2. ANOVA results for the extraction yield and TPC

Çizelge 2. Ekstraksiyon verimi ve toplam fenolik içeriği (TPC) için ANOVA sonuçları

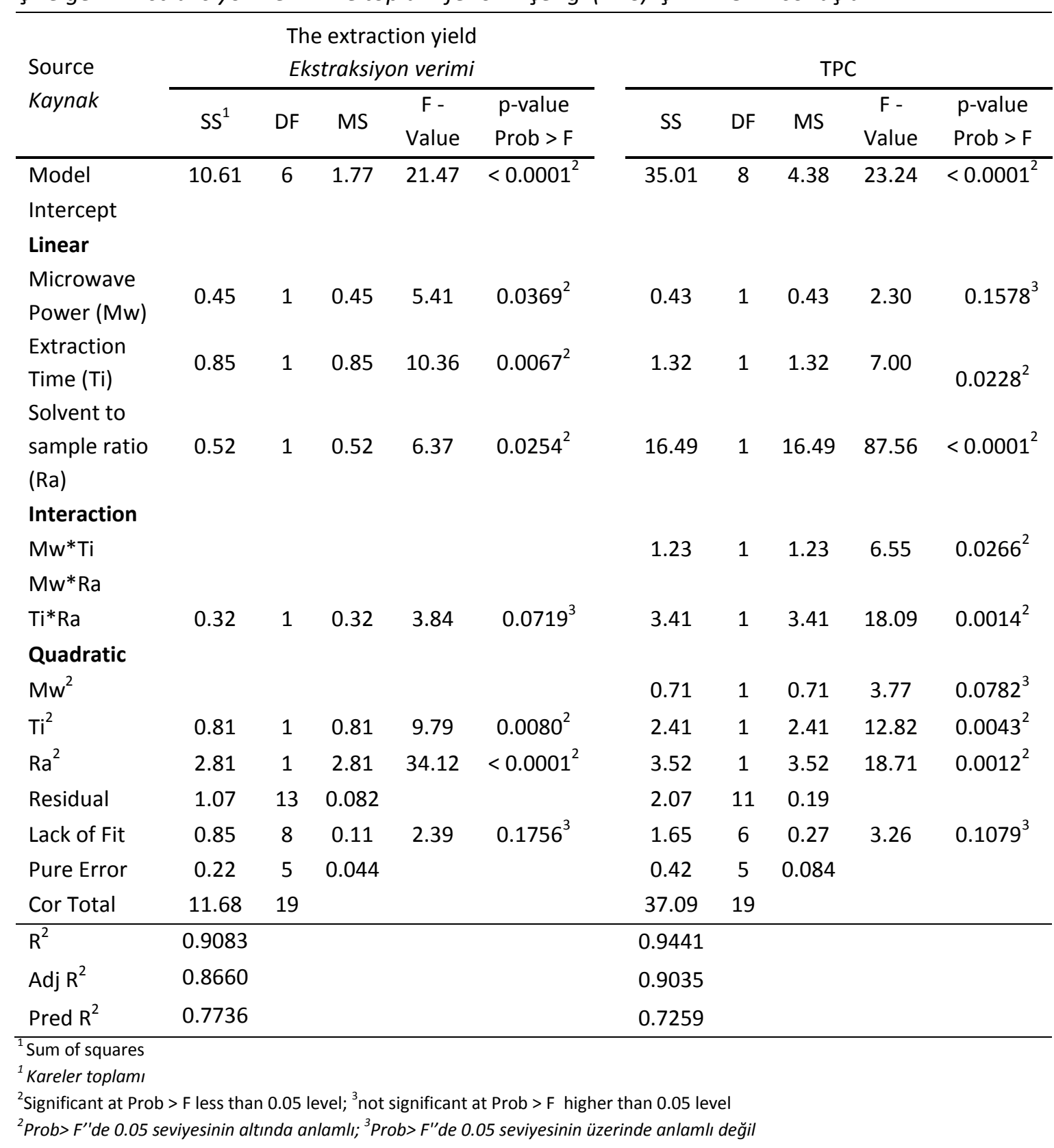

Three dimensional response surface curves and contour plots (Figure 1 and 2) were used to show the effects of process variables on the responses. The response surface and contour plots indicated that the effect of two variables on the dependent variable described by the quadratic polynomial equation while third variable was kept constant at middle level, $15: 1 \mathrm{~mL} \mathrm{~g}^{-1}$ (solvent to sample ratio), $9 \mathrm{~min}$ (extraction time) and $200 \mathrm{~W}$ (microwave power). 

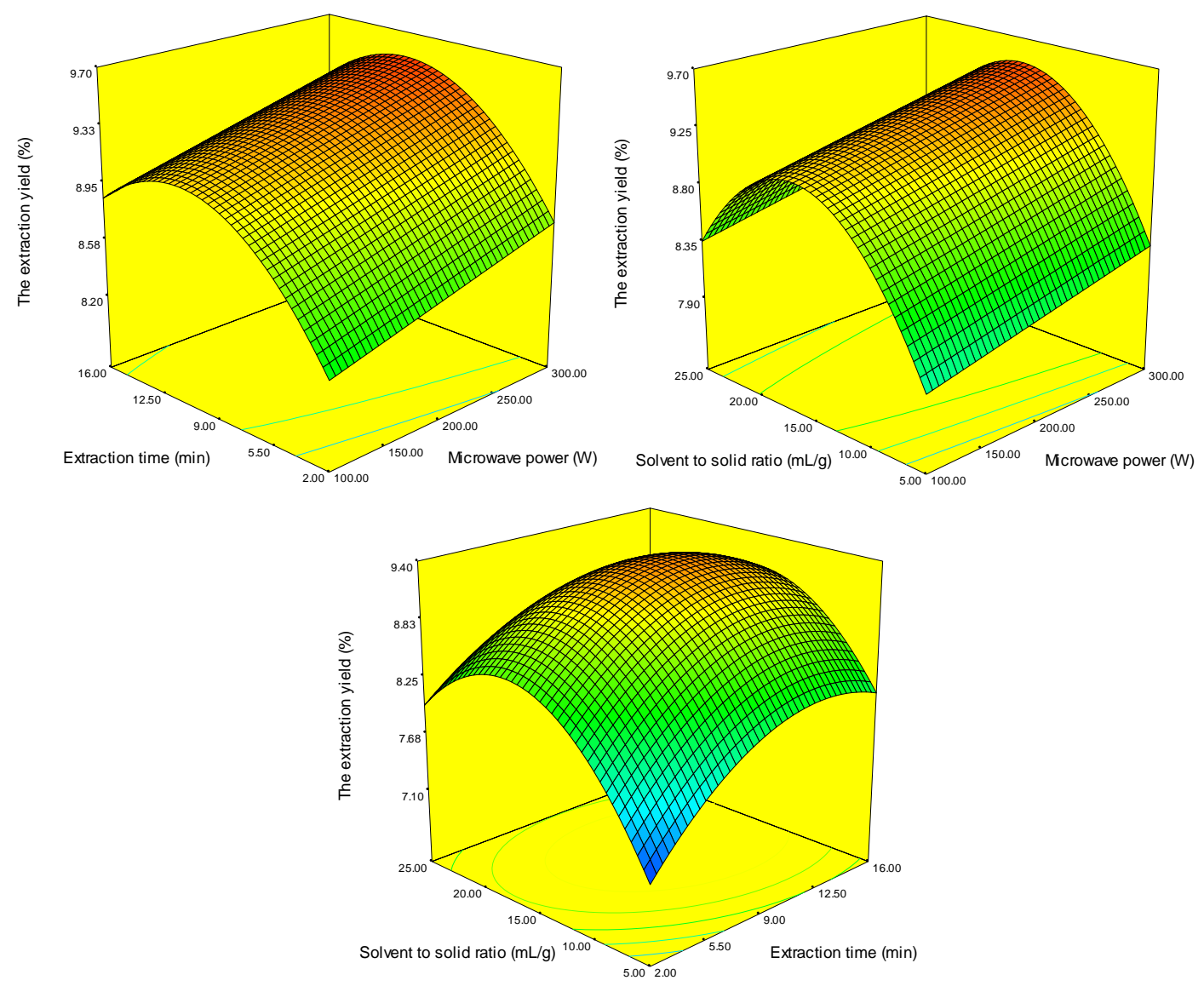

Figure 1. Response surface plots between coupled independent variables for the extraction yield

Şekil 1. Eşleştirilmiş bağımsı değiş̧kenler arasında ekstraksiyon verimi açısından yanıt yüzey grafikleri

The effect of microwave power on the extraction yield and TPC

The effects of microwave power in range 100 to $300 \mathrm{~W}$ were investigated on the extraction yield and TPC. Microwave power displayed significant $(p<0.05)$ positive linear effect on the extraction yield. Extraction yield went up linearly with increase of microwave power (Figure 1). Short extraction time for MAE might lead to the linear increase of microwave power on the extraction yield (Sinha et al., 2012; Wang et al., 2007). Moreover, increase in microwave power results in the rupture of the cell walls and enhance the extraction yield due to easier penetration of the solvent into the plant matrix (Mendes et al., 2016).

It was found that linear effect of microwave power has no significant $(p>0.05)$ effect on TPC extracted from strawberry (Table 2). In other words, phenolic extraction of strawberry can be conducted easily in a short time without the necessary high microwave power. Similar results were reported by some authors who studied the effect of microwave power on extraction of flavonoids (Gao et al., 2006; Chen et al., 2008; Garofulic et al., 2013). Figure 2 shows interaction between microwave power and extraction time on TPC. Even though microwave power did not seem to be 
significant, its interaction with extraction time was observed as negatively significant $(p<0.05)$ according to the ANOVA results (Table 2). It can be interpreted that increasing microwave power with decreasing extraction time or vice versa result in higher amount of phenolics extracted. In other words, high microwave power is only preferable with short extraction time to prevent the degradation of phenolic compounds (Ballard et al., 2010).
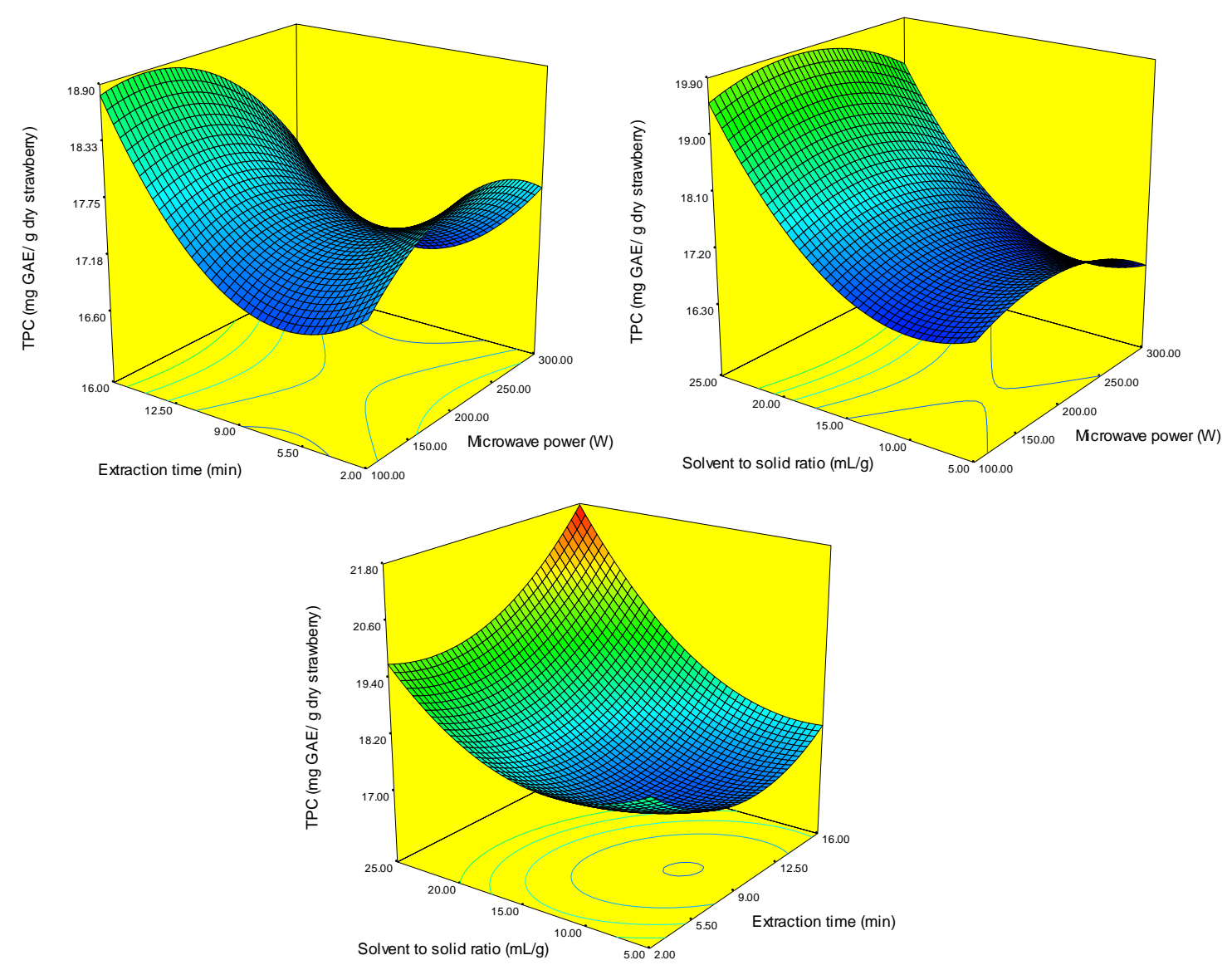

Figure 2. Response surface plots between coupled independent variables for TPC

Şekil 2. Eşleştirilmiş bağımsız değişkenler arasında toplam fenolik içerik (TPC) açısından yanıt yüzey grafikleri

The effect of extraction time on the extraction yield and TPC

When the effect of time on the extraction yield was evaluated, the most effective process variable was extraction time with its lowest $p$ value and the highest $F$ value (Table 2). Extraction time significantly $(p<0.05)$ affected the extraction yield in both positively linear and negatively quadratic manner. It could be explicated that the extraction yield increased with the increase of the extraction time, and nearly reached a peak at the highest extraction time tested (Figure 1).

It was observed that extraction time had considerably effect on TPC along with solvent to sample ratio. Positive coefficients for extraction time depicted linear effects 
that increase TPC. Additionally, extraction time and solvent to sample ratio have significant positive interactive influences on TPC when microwave power was kept at 200 W. It was determined that extraction time had positive quadratic effect.

The effect of solvent to sample ratio on the extraction yield and TPC

Solvent to sample ratio with positive linear regression coefficient showed significant effect $(\mathrm{p}<0.05)$ on the extraction yield (Table 2). Also, the effect of solvent to sample ratio on the extraction yield was found to increase up to $20: 1$ solvent to sample ratio and later decreased with further solvent to sample ratio due to its positive linear and negative quadratic effect.

Solvent to sample ratio was determined as the most effective independent variable for TPC. Solvent to sample ratio has a significantly $(p<0.05)$ positive effect on total phenolics extracted. This means that, the amount of phenolics extracted from strawberry increases as solvent to sample ratio increases. Pinelo et al. (2005) and Zheng et al. (2013) were reported similar results about the effect of solvent to sample ratio on the extraction of phenolic compounds.

\section{Model optimization and verification}

Optimal conditions of MAE were determined using FCCCD. The optimum conditions were predicted as $265 \mathrm{~W}$ of microwave power, 2 min of extraction time, 24:1 $\mathrm{g} \mathrm{mL}^{-1}$ of solvent to sample ratio to obtain maximum values of extraction yield (8.23\%) and TPC (19.65 mg GAE g ${ }^{-1}$ dry strawberry). Predicting the optimal response values has to be tested to determine accuracy of the models. For this purpose, MAE from strawberry was carried out in triplicate under optimal conditions and predicted values and experimental values were compared to each other. Experimental results were satisfactorily close to the predicted values. Therefore, it was proved that predicted values of model responses were satisfactory and accurate.

Some properties of strawberry extracts obtained at optimum conditions

Once optimum conditions of MAE from strawberry were determined, some additional analyses were carried out to determine TAC and antioxidant activity of strawberry extracts obtained at optimum condition. The effect of MAE on recovery of anthocyanin and antioxidant activity of extracts was evaluated to compare them before and after extraction (Table 3). TAC results were determined as 2.92 and $2.30 \mathrm{mg}$ Cyn-3-glu g ${ }^{-1}$ dry strawberry before and after extraction, respectively. Results show that a high amount of anthocyanins, using MAE technique could be extracted from strawberry without degrading. Degradation of anthocyanins might be prevented due to short processing time of MAE. In addition to anthocyanins content in extracts, their antioxidant capacities were also assessed, using DPPH and FRAP methods. DPPH.EC 50 values of samples before and after extraction were found as 1.31 and $1.67 \mathrm{mg}$ dry strawberry $\mathrm{mL}^{-1}$, respectively. FRAP values of samples before and after extraction were 215.28 and 197.83 umoles TE $\mathrm{g}^{-1}$ dry strawberry, respectively. It was understood from the results that antioxidant compounds in strawberry fruit could be extracted effectively by using MAE. These results also confirm that functional properties of phenolics, especially anthocyanins in strawberry were preserved after MAE. 
Table 3. Comparison of TPC, TAC, DPPH and FRAP values before and after extraction Çizelge 3. Ekstraksiyon öncesi ve sonrası TPC, TAC, DPPH ve FRAP değerlerinin karşılaştırılması

\begin{tabular}{|c|c|c|c|c|}
\hline & $\mathrm{TPC}^{1}$ & $\mathrm{TAC}^{2}$ & $\mathrm{DPPH} \cdot \mathrm{EC}_{50}^{3}$ & FRAP $^{4}$ \\
\hline $\begin{array}{l}\text { Before extraction } \\
\text { Ekstraksiyon öncesi }\end{array}$ & 22.15 & 2.92 & 1.31 & 215.28 \\
\hline $\begin{array}{l}\text { After extraction } \\
\text { Ekstraksiyon sonrası }\end{array}$ & 19.65 & 2.30 & 1.67 & 197.83 \\
\hline 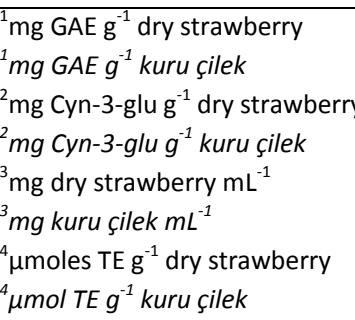 & & & & \\
\hline
\end{tabular}

\section{Conclusion}

In the present study, phenolics in strawberry fruit could be efficiently extracted using optimized MAE technique. All of independent variables (microwave power, extraction time and solvent to sample ratio) showed a significant effect on extraction yield. However, microwave power did not show significant effect on TPC. Extraction time and solvent to sample ratio influenced the TPC significantly. Extraction time was the most significant variable on the extraction yield, followed by solvent to sample ratio whereas the most effective variable on TPC was solvent to sample ratio, followed by extraction time. Microwave power was the least significant variable for both the extraction yield and TPC. Results of DPPH and FRAP were also proved that the extracts produced at optimum conditions had high antioxidant activity. As a result, MAE is an efficient technique with high extraction yield and short time to extract the valuable compounds from strawberry.

\section{Acknowledgements}

Financial support for this project is provided by funding bodies within the FP7
ERA-Net CORE Organic Plus (618107), and with cofunds from the European Commission. We would also like to thank Bursa central research institute of food and feed control for financial support.

\section{References}

Ayala-Zavala, J. F., Wang, S. Y., Wang, C. Y., González-Aguilar, G. A., 2007. High oxygen treatment increases antioxidant capacity and postharvest life of strawberry fruit. Food Technology and Biotechnology, 45 (2): 166-173.

Azmir, J., Zaidul, I. S. M., Rahman, M. M., Sharif, K. M., Mohamed, A., Sahena, F., Jahurul, M. H. A., Ghafoor, K., Norulaini, N. A. N., Omar, A. K. M., 2013. Techniques for extraction of bioactive compounds from plant materials: A review. Journal of Food Engineering, 117 (4): 426-436.

Bai, X., Qiu, A., Guan, J., 2007. Optimization of microwave-assisted extraction of antihepatotoxic triterpenoid from Actinidia deliciosa root and its comparison with conventional extraction methods. Food Technology \& Biotechnology, 45 (2): 174-180.

Ballard, T. S., Mallikarjunan, P., Zhou, K. Q., O'Keefe, S., 2010. Microwave-assisted extraction of phenolic antioxidant compounds from peanut skins. Food Chemistry, 120 (4): 1185-1192.

Benzie, I. F. F., Strain, J. J., 1996. The ferric reducing ability of plasma (FRAP) as a measure of "antioxidant power": The 
FRAP assay. Analytical Biochemistry, 239 (1): 70-76.

Brandwilliams, W., Cuvelier, M. E., Berset, C., 1995. Use of a free-radical method to evaluate antioxidant activity. Food Science and Technology (LWT), 28 (1): 25-30.

Carniel, N., Dallago, R. M., Dariva, C., Bender, J. P., Nunes, A. L., Zanella, O., Bilibio, D., Luiz Priamo, W., 2016. Microwave-assisted extraction of phenolic acids and flavonoids from Physalis angulata. Journal of Food Process Engineering, 40(3): 1-11.

Chan, C. H., Yusoff, R., Ngoh, G. C., Kung, F. W. L., 2011. Microwave-assisted extractions of active ingredients from plants. Journal of Chromatography A, 1218 (37): 6213-6225.

Chen, L., Jin, H., Ding, L., Zhang, H., Li, J., Qu, C., Zhang, H., 2008. Dynamic microwaveassisted extraction of flavonoids from Herba epimedii. Separation and Purification Technology, 59 (1): 50-57.

Del Rio, D., Borges, G., Crozier, A., 2010. Berry flavonoids and phenolics: bioavailability and evidence of protective effects. British Journaol of Nutrition, 104 Suppl 3: S67-90.

Food and Agriculture Organization (FAOSTAT). Statistical Database; 2014. Available from http://faostat.fao.org.

Fortalezas, S., Tavares, L., Pimpão, R., Tyagi, M., Pontes, V., Alves, P. M., McDougall, G., Stewart, D., Ferreira, R. B., Santos, C. N., 2010. Antioxidant properties and neuroprotective capacity of strawberry tree fruit (Arbutus unedo). Nutrients, 2 (2): 214-229.

Gao, M., Song, B. Z., Liu, C. Z., 2006. Dynamic microwave-assisted extraction of flavonoids from Saussurea medusa Maxim cultured cells. Biochemical Engineering Journal, 32 (2): 79-83.

Garcia-Salas, P., Morales-Soto, A., SeguraCarretero, A., Fernandez-Gutierrez, A., 2010. Phenolic compound extraction systems for fruit and vegetable samples. Molecules, 15 (12): 8813-8826.

Garofulic, I. E., Dragovic-Uzelac, V., Jambrak, A. R., Jukic, M., 2013. The effect of microwave assisted extraction on the isolation of anthocyanins and phenolic acids from sour cherry Marasca (Prunus cerasus var. Marasca). Journal of Food Engineering, 117 (4): 437-442.

Hornedo-Ortega, R., Krisa, S., Garcia-Parrilla, M. C., Richard, T., 2016. Effects of gluconic and alcoholic fermentation on anthocyanin composition and antioxidant activity of beverages made from strawberry. Food Science and Technology (LWT), 69: 382-389.

Huang, W. Y., Cai, Y. Z., Zhang, Y., 2009. Natural phenolic compounds from medicinal herbs and dietary plants: Potential use for cancer prevention. Nutrition and cancer, 62 (1): 1-20.

Kafkas, E., Koşar, M., Paydaş, S., Kafkas, S., Başer, K. H. C., 2007. Quality characterictics of strawberry genotypes at different maturation stages. Food Chemistry, 100 (3): 1229-1236.

Kaufmann, B., Christen, P., 2002. Recent extraction techniques for natural products: Microwave-assisted extraction and pressurised solvent extraction. Phytochemical Analysis, 13 (2): 105-113.

Lee, J., Durst, R. W., Wrolstad, R. E., 2005. Determination of total monomeric anthocyanin pigment content of fruit juices, beverages, natural colorants, and wines by the $\mathrm{pH}$ differential method: Collaborative study. Journal of AOAC International, 88 (5): 1269-1278.

Ljevar, A., Ćurko, N., Tomašević, M., Radošević, K., Srček, V. G., Ganić, K. K., 2016. Phenolic composition, antioxidant capacity and in vitro cytotoxicity assessment of fruit wines. Food Technology and Biotechnology, 54(2): 145-155.

Mandal, V., Mohan, Y., Hemalatha, S., 2007. Microwave assisted extraction-an innovative and promising extraction tool for medicinal plant research. Pharmacognosy Reviews, 1 (1): 7-18.

Mendes, M., Carvalho, A. P., Magalhaes, J. M. C. S., Moreira, M., Guido, L., Gomes, A. M., Delerue-Matos, C., 2016. Response surface evaluation of microwave-assisted extraction conditions for Lycium barbarum bioactive compounds. Innovative Food Science \& Emerging Technologies, 33: 319326.

Nile, S. H., Park, S. W., 2014. Edible berries: Bioactive components and their effect on human health. Nutrition, 30 (2): 134-144.

Nohynek, L. J., Alakomi, H.-L., Kähkönen, M. P., Heinonen, M., Helander, I. M., OksmanCaldentey, K.-M., Puupponen-Pimiä, R. H., 2006. Berry phenolics: antimicrobial properties and mechanisms of action against severe human pathogens. Nutrition and cancer, 54 (1): 18-32. 
Paredes-Lopez, O., Cervantes-Ceja, M. L., VignaPerez, M., Hernandez-Perez, T., 2010. Berries: improving human health and healthy aging, and promoting quality life-a review. Plant Foods Human Nutrition, 65 (3): 299-308.

Pinelo, M., Rubilar, M., Jerez, M., Sineiro, J., Nunez, M. J., 2005. Effect of solvent, temperature, and solvent-to-solid ratio on the total phenolic content and antiradical activity of extracts from different components of grape pomace. Journal of Agricultural and Food Chemistry, 53 (6): 2111-2117.

Sargent, D. J., Rys, A., Nier, S., Simpson, D. W., Tobutt, K. R., 2007. The development and mapping of functional markers in Fragaria and their transferability and potential for mapping in other genera. Theoretical and Applied Genetics, 114 (2): 373-384.

Singleton, V. L., Orthofer, R., Lamuela-Raventos, R. M., 1999. Analysis of total phenols and other oxidation substrates and antioxidants by means of Folin-Ciocalteu reagent. Methods in Enzymology, 299: 152-178.

Sinha, K., Das Saha, P., Datta, S., 2012. Response surface optimization and artificial neural network modeling of microwave assisted natural dye extraction from pomegranate rind. Industrial Crops and Products, 37 (1): 408-414.

Wang, S. J., Chen, F., Wu, J. H., Wang, Z. F., Liao, X. J., Hu, X. S., 2007. Optimization of pectin extraction assisted by microwave from apple pomace using response surface methodology. Journal of Food Engineering, 78 (2): 693-700.

Wu, T., Yan, J., Liu, R. H., Marcone, M. F., Aisa, H. A., Tsao, R., 2012. Optimization of microwave-assisted extraction of phenolics from potato and its downstream waste using orthogonal array design. Food Chemistry, 133 (4): 1292-1298.

Yang, J., Liu, R. H., 2009. Induction of phase II enzyme, quinone reductase, in murine hepatoma cells in vitro by grape extracts and selected phytochemicals. Food Chemistry, 114 (3): 898-904.

Zhang, H., Tsao, R., 2016. Dietary polyphenols, oxidative stress and antioxidant and antiinflammatory effects. Current Opinion in Food Science, 8: 33-42.

Zheng, X., Xu, X., Liu, C., Sun, Y., Lin, Z., Liu, H., 2013. Extraction characteristics and optimal parameters of anthocyanin from blueberry powder under microwaveassisted extraction conditions. Separation and Purification Technology, 104: 17-25. 